\title{
Forage quality of leaf fodder from the main woody species in Iceland and its potential use for livestock in the past and present
}

\author{
M. Hejcman*, †, P. Hejcmanováł, V. Pavlư* and A. G. Thorhallsdottir§ \\ *Department of Ecology, Faculty of Environmental Sciences, Czech University of Life Sciences, Prague 6- \\ Suchdol, Czech Republic, †'Department of Archaeology, Faculty of Arts, University of Hradec Králové, Hradec \\ Králové, Czech Republic, \$Faculty of Tropical AgriSciences, Czech University of Life Sciences, Prague 6- \\ Suchdol, Czech Republic, §Department of Natural Resources, Faculty of Environmental Sciences, Agricultural \\ University of Iceland, Borgarnes, Iceland
}

\begin{abstract}
Woody species played, and in many Nordic regions still play, a very important role in livestock feeding. However, forage quality (contents of macroelements and fibre fractions) of the leaves of common woody species is often inadequate. The aim of our study was to determine forage quality of leaves of Betula nana, Betula pubescens, Salix lanata, Salix phylicifolia and Sorbus aucuparia from Iceland and to compare it with the forage quality of the common native grass Deschampsia cespitosa and the introduced grass Alopecurus pratensis used by contemporary Icelandic farmers for forage production. Samples were collected at four localities in Iceland in late June 2013 and analysed for nitrogen $(\mathrm{N})$, phosphorus $(\mathrm{P})$, potassium $(\mathrm{K})$, calcium (Ca), magnesium $(\mathrm{Mg})$, neutral and acid-detergent fibre and lignin concentration. Analyses were compared with the optimum range for cattle and sheep nutrition. The nutritive value of leaves of the Icelandic woody species was relatively high, and analysis showed their nutritive content satisfied both cattle and sheep nutrient requirements for $\mathrm{N}, \mathrm{P}, \mathrm{K}, \mathrm{Ca}$ and $\mathrm{Mg}$, but the relatively high content of indigestible lignin in all woody species could cause problems for livestock metabolism. Grasses were characterized by lower P, Ca and $\mathrm{Mg}$, but substantially higher $\mathrm{K}$ concentrations, and higher $\mathrm{N}: \mathrm{P}$ and $\mathrm{K}:(\mathrm{Mg}+\mathrm{Ca})$ ratios. The forage quality of leaves of woody species increased in the order $B$. nana $<$ B. pubescens $<S$. phylicifolia $<S$. aucu-
\end{abstract}

Correspondence to: P. Hejcmanová, Faculty of Tropical AgriSciences, Czech University of Life Sciences, Kamýcká 129, Prague 6-Suchdol 16521, Czech Republic.

E-mail: hejcmanova@ftz.czu.cz

Received 9 July 2015; revised 21 December 2015 paria $<S$. lanata. Results are discussed in relation to use of leaf fodder in the past, when woody species, particularly Salix spp., are likely to have played an important role in livestock feeding.

Keywords: agricultural history, leaf fodder, livestock feeding, North Atlantic islands, nutritive value

\section{Introduction}

In high-latitude areas of the Northern Hemisphere, with short growing seasons and limited possibilities for cultivation, human subsistence has relied heavily on animal products. In the North Atlantic islands, the extent of arable farming was negligible and crop production was restricted to barley (Hordeum vulgare) in the most favourable areas (Simpson et al., 2002; Hannon et al., 2005; Church et al., 2013). Animal products from hunting and fishing were important in some areas, particularly for indigenous groups in Greenland. For the Norse cultures, however, the main source of animal products was livestock husbandry (Dugmore et al., 2012). The colonization of the North Atlantic islands by Norse settlers (AD 500-900) was associated with the spread of livestock (cattle, caprine, pigs and horses) (Dugmore et al., 2005; McGovern et al., 2007) brought into the pristine ecosystems of the northern islands. With the exception of avian herbivores, these ecosystems had developed without grazing pressure by large herbivores, resulting in vegetation that was low in defence mechanisms (Bryant and Kuropat, 1980; Bryant et al., 1989). Defence mechanisms are especially found in browse woody species and are often induced by herbivory (Kohi et al., 2009). Leaves of woody species usually have high nutritive value compared to grasses, which makes them attractive to herbivores, especially if the plants are also low in defence 
mechanisms (Bryant et al., 2014). Therefore, woody species must have been attractive as forage for livestock during the first period of settlement in the North Atlantic islands, and many settlers, with experience from their home country, are likely to have made good use of this source of forage for their livestock (Hjelle, 1999). Direct evidence for the composition of animal diets from the Norse landnám period is limited, and to our knowledge, there are no archaeological records from Iceland that document livestock diets. There is limited evidence, however, from coprolites and mediaeval middens (Ross and Zutter, 2007) and indirect information from teeth of sheep and goats from Greenland (Mainland, 2006), which indicates that heathland shrubs were an important resource for caprines, including Betula nana and Salix spp. Recent palaeoecological investigations in Greenland also provide additional indirect evidence of grazing management on birch woodland and dwarf shrub heath communities (Schofield and Edwards, 2011; Ledger et al., 2014a,b), suggesting also leaf and twig foddering of Betula sp. (Ledger et al., 2015). Because of the low content of secondary compounds for defence, the use of leaf-hay fodder as a high-nutrition feed source is also therefore very likely to have been widespread in Iceland (McGovern et al., 2007). Given their high importance as a limited resource, birch woodlands in Greenland and Iceland were probably managed in a relatively sustainable way, and there is evidence for regulation and management of fuel resources, at least for some time after settlement (Simpson et al., 2003; Vésteinsson and Simpson, 2004; McGovern et al., 2007; Schofield and Edwards, 2011). This resource, however, would become limited; most studies show there was a decline of Betula pubescens woodlands in Iceland and Greenland during the centuries following settlement (Edwards et al., 2008; Ledger et al., 2015), probably due to interactions between climatic deterioration and land use (i.e. grazing, as well as iron production and charcoal making) (Dugmore et al., 2006; Lawson et al., 2007; McGovern et al., 2007; Erlendsson and Edwards, 2009).

The Norse farmers in Iceland continued in the tradition of shieling areas for milking livestock at the edge of the farms, as practised in Norway, and used communal rangeland grazing areas for the rest of livestock during the summer (Thomson and Simpson, 2007; Brown et al., 2012). In the sheep-and-cattle-based economy in Iceland, winter housing for animals and ensuring enough winter fodder collection were essential for their survival (Dugmore et al., 2005). Winter fodder was mainly grass hay from home fields but also, to a large degree, from forage cut from natural pastures; that is, natural grasslands, extensive wetlands and leaf-hay fodder harvested in adjacent woodlands, especially in some parts of the country (Church et al., 2007; Gudmundsson, 2015).

The Icelandic woodlands, dominated by B. pubescens and Salix spp., declined after the Norse colonization in the 9th century (McGovern et al., 2007). This decline has been attributed to changes in land use: forest clearing, livestock grazing, wood collection needed for cooking and for charcoal making to fuel extensive iron production (Fridriksson and Hermanns-Audardóttir, 1991; Church et al., 2007; Trbojević et al., 2011) and intensified by the worsening climate and volcanism after the 13th century (Ogilvie and Jónsson, 2000; Sigurmundsson et al., 2014). The importance of woodlands as a source of leaf fodder in Iceland is very poorly documented, but different sources have implied important use of leaf fodder historically in Iceland (Sigvaldason, 1967; Gunnlaugsson, 1969; Sigurmundsson et al., 2014), especially in the northeast and east of Iceland (Gudmundsson, 2015). Although woody species most likely played an important role in livestock feeding, in both winter and summer, forage quality (as nutritive value) of the leaves of common woody species, in terms of macroelements and fibre fraction concentrations and their effects on animal nutrition, has not been investigated to any detail in Iceland; see, however, Sigvaldason (1967) and Gunnlaugsson (1969).

Although often an important component in livestock diets, there has been relatively little attention paid to the forage quality of browse vegetation in the Nordic regions. In recent years, however, interest in the nutritional value of browse and woody species has been increasing, especially in relation to their content of secondary compounds, particularly tannins and their effect on parasite burden and on ruminal methane production (Tedeschi et al., 2014; Villalba et al., 2014). Further, the effect of the interaction of browsing and climate change on the spread of woody vegetation in the Arctic tundra has come into focus (Bryant et al., 2014). Therefore, further information on the nutritional value of browse and its use as forage is of renewed interest.

The aim of this study was to determine the forage quality of leaves of some common woody species (B. nana, B. pubescens, Salix lanata, Salix phylicifolia and Sorbus aucuparia) in Iceland and to compare it with the forage quality of the common native grass Deschampsia cespitosa and with the high yielding, cultivated grass Alopecurus pratensis, introduced from elsewhere in Europe (Kristinsson, 2013) and which is common in Icelandic hayfields used for winter forage production (Helgadóttir et al., 2013). From these results, we discuss forage quality of leaf fodder in relation to the nutritional requirements of livestock and the possible consequences of forage quality of different 
woody species following their selection by livestock, leaf-fodder harvesting and the development of forest vegetation under farming management.

\section{Materials and methods}

\section{Biomass sampling}

We selected five common broad-leaved woody species (Betula nana subsp. nana, B. pubescens, S. lanata, S. phylicifolia and S. aucuparia) and two grass species (D. cespitosa and A.pratensis) for biomass sampling (Figure S2 gives further information about the investigated species). From these, leaf biomass (fully expanded leaves, blades and petioles together for woody species and sward biomass for grasses) was selected and mixed from at least three individuals for one sample on each of four samples per species in late June 2013. Samples were collected at four localities in Iceland: in the surroundings of Gullfoss $\left(64^{\circ} 19^{\prime} \mathrm{N}, \quad 20^{\circ} 07^{\prime} \mathrm{W}\right), \quad$ Akureyri $\left(65^{\circ} 41^{\prime} \mathrm{N}, 18^{\circ} 10 \mathrm{~W}\right)$, Godafoss $\left(65^{\circ} 40^{\prime} \mathrm{N}, 17^{\circ} 33^{\prime} \mathrm{W}\right)$ and Húsavík $\left(66^{\circ} 02^{\prime} \mathrm{N}\right.$, $17^{\circ} 20^{\prime} \mathrm{W}$ ). A total 20 (five woody species $\times$ four replicates) leaf biomass samples and eight above-ground biomass samples (leaves, stems and inflorescences together, cut at $5 \mathrm{~cm}$ above the ground) were collected and oven-dried at $60^{\circ} \mathrm{C}$ for $48 \mathrm{~h}$ and ground to powder.

\section{Biomass chemical properties}

In biomass samples, the concentration of macroelements $(\mathrm{N}, \mathrm{P}, \mathrm{K}, \mathrm{Ca}, \mathrm{Mg})$ and the content of residual ash (i.e. ash $-(\mathrm{P}+\mathrm{K}+\mathrm{Ca}+\mathrm{Mg}))$ neutral- and aciddetergent fibre (NDF and ADF) and acid-detergent lignin were determined. NDF represents cellulose, hemicellulose and lignin together; ADF represents cellulose and lignin. The $\mathrm{N}$ concentration in the plant samples was determined using an automated analyser (TruSpec, LECO Corporation, St Joseph, MI, USA) by combustion with oxygen in an oven at $950^{\circ} \mathrm{C}$. Combustion products were mixed with oxygen, and the mixture passed through an infrared detector of $\mathrm{CO}_{2}$ and by circuit for the aliquot ratio where carbon is measured as $\mathrm{CO}_{2}$. Gases in the aliquot circuit were transferred into helium as a carrying gas, conducted through hot copper and converted to N.

Biomass samples were burnt in a microwave oven at a temperature of $550^{\circ} \mathrm{C}$ and weighed to determine ash content. Biomass samples were mineralized using aqua regia, and $\mathrm{P}, \mathrm{K}, \mathrm{Ca}$ and $\mathrm{Mg}$ concentrations were then determined in the solution using ICP-OES (Varian VistaPro, Mulgrave, Vic., Australia). Residual ash containing mostly Si was calculated as the ash content minus the sum of $\mathrm{P}, \mathrm{K}, \mathrm{Ca}$ and $\mathrm{Mg}$ concentrations.
Contents of NDF, ADF and ADL were determined by standard methods of AOAC (1984).

All analyses were performed in an accredited national laboratory, Ekolab Žamberk (http://www. ekolab.zamberk.cz). The ratios of N:P, Ca:P and $\mathrm{K}:(\mathrm{Ca}+\mathrm{Mg})$ were calculated from determined concentrations.

\section{Data analyses}

Data tested by the Kolmogorov-Smirnov test of normality met assumptions for the use of parametric tests. One-way ANova followed by post hoc comparison using the Tukey's multiple range tests in Statistica 9.0 (StatSoft, Tulsa, OK, USA) was used to identify significant differences in concentrations of nutrients and NDF, $\mathrm{ADF}$ and lignin contents among species.

Unconstrained principal component analysis (PCA) in the Canoco for Windows 4.5 program (ter Braak and Šmilauer, 2002) was used to analyse the relationships among biomass chemical properties and the similarity of the twenty-eight samples. Data were centred and standardized before the analysis. The results of the PCA analysis were visualized in the form of an ordination diagram constructed by the CanoDraw program (ter Braak and Šmilauer, 2002).

\section{Results}

With the exception of $\mathrm{N}$, all analysed chemical properties were significantly different among plant species. Concentration of $\mathrm{N}, \mathrm{P}, \mathrm{Ca}$ and $\mathrm{Mg}$, and ratios $\mathrm{Ca}: \mathrm{P}$ and $\mathrm{K}:(\mathrm{Mg}+\mathrm{Ca})$ were higher in woody species than in grasses, but the $\mathrm{K}$ concentration and $\mathrm{N}: \mathrm{P}$ ratio were higher in grasses than in woody species (Table 1). Contents of NDF and ADF were lower in woody species than in grasses, being highest in S. phylicifolia and lowest in A. pratensis. Content of lignin was substantially higher in woody species than in grasses, but residual ash was lower in woody species in comparison with grasses (Table 2).

The relationship between all analysed chemical properties in all species is well differentiated by the PCA ordination diagram (Figure 1). The first axis of the diagram explained $50 \%$ of data variability, and the first two axes together explained $71 \%$ of data variability. The first axis divided the analysed species into woody species on the left side and grasses on the right side of the diagram. Grasses were characterized by higher $\mathrm{K}$ concentration, residual ash, NDF and ADF content, $\mathrm{K}:(\mathrm{Ca}+\mathrm{Mg})$ and $\mathrm{N}: \mathrm{P}$ ratios. Woody species, on the other hand, were characterized by higher N, P, $\mathrm{Ca}$ and $\mathrm{Mg}$ concentrations, lignin content and $\mathrm{Ca}: \mathrm{P}$ ratio. Four replications for each species made clearly visible clusters in the ordination diagram, indicating 


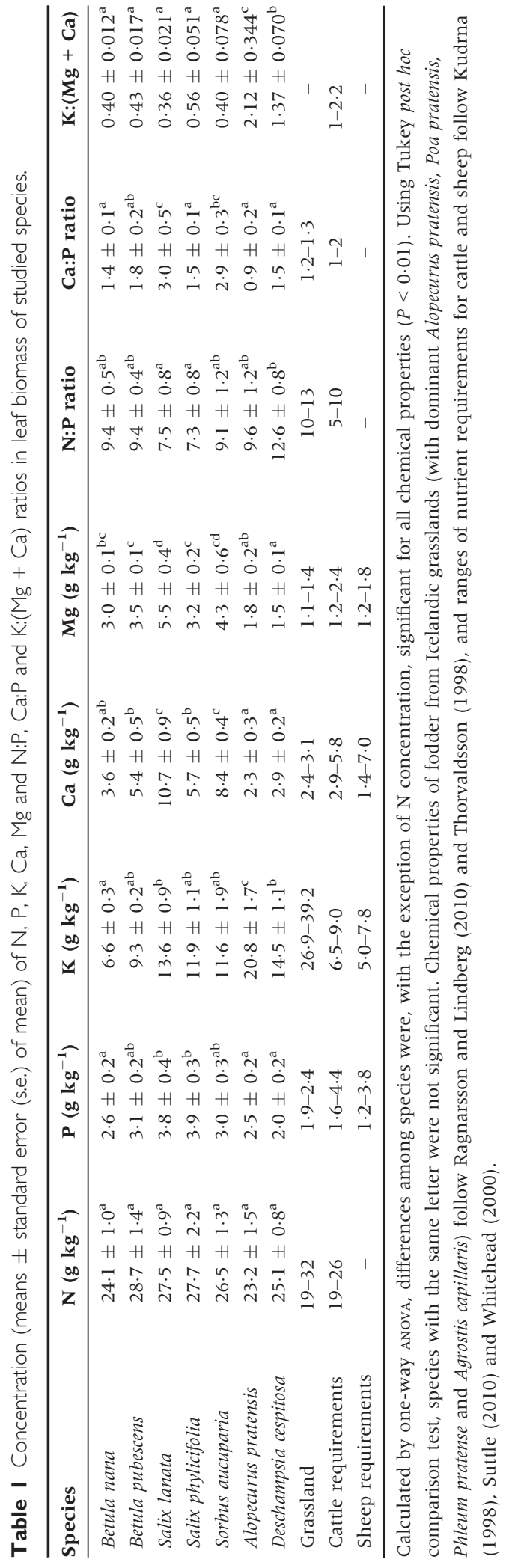

that the effect of species on the analysed chemical properties was substantially higher than the effect of locality. Very low intraspecies variability in the analysed chemical properties was recorded, particularly for B. nana, B. pubescens, S. phylicifolia and D. cespitosa as marks for all replications were close together in the diagram.

\section{Discussion}

\section{Forage quality of leaves of woody species and two grass species}

The results of our study show that concentrations of macroelements in the leaves of all the Icelandic browse species were well within the optimum range of nutritional requirements for cattle and sheep, in terms of requirements for maintenance, growth, pregnancy and lactation, and were comparable to the results obtained for meadow hay from Icelandic grasslands (Table 1). The $\mathrm{P}$ concentrations in samples of S. phylicifolia and S. lanata were very high, and even close to the upper limit of the requirements of highly productive dairy cattle in lactation (Whitehead, 2000). Very high interspecies differences in $\mathrm{K}$ concentrations were recorded, particularly between leaves of woody species and grasses. Only in B. nana and B. pubescens were the $\mathrm{K}$ concentrations within the optimum range for cattle and sheep. In all other species, K concentrations exceeded nutritional requirements. The concentrations of $\mathrm{Ca}$ and $\mathrm{Mg}$ were higher in leaves of woody species than in the meadow hay. Both were mostly at the upper limit or above the limit of the optimum range for livestock requirements, consequently resulting in a low 'tetany ratio' $(\mathrm{K}:(\mathrm{Ca}+\mathrm{Mg}))$. The $\mathrm{N}: \mathrm{P}$ ratio was within the optimum range in all species except $D$. cespitosa where it was too high.

The Ca:P ratio was slightly below the optimum range in $A$.pratensis and above the optimum in S. lanata and $S$. aucuparia. The $\mathrm{K}:(\mathrm{Ca}+\mathrm{Mg})$ ratio was below the optimum range in all woody species and within the optimum range in both of the grasses, A. pratensis and $D$. cespitosa.

Very high $\mathrm{P}$ concentrations were recorded in the leaves of both Salix species. These P concentrations were greater than values recorded in young leaves of dominant woody species in Central Europe (Hejcmanová et al., 2014). A possible explanation is that concentrations of $\mathrm{P}$ and forage quality increase with latitude because of higher radiation, lower temperatures and slower plant growth (Reich and Oleksyn, 2004).

Optimum NDF content for cattle nutrition was recorded only in S. lanata. Both Betula species were at the lower limit of requirements, and other woody 
Table 2 Concentration (means \pm s.e. of mean) of neutral detergent fibre (NDF), acid-detergent fibre (ADF), lignin and residual ash in leaf biomass of studied species.
Figure I Ordination diagram showing results of PCA of relationships among chemical properties of biomass of studied species, N, P, K, Ca and $\mathrm{Mg}$ concentrations; $\quad \mathrm{N}: \mathrm{P}, \quad \mathrm{Ca}: \mathrm{P}$ and $\mathrm{K}$ : $(\mathrm{Ca}+\mathrm{Mg})$ ratios, residual ash (Res.Ash), NDF (neutral detergent fibre), ADF (acid-detergent fibre) and lignin. Species abbreviations: AloPra, Alopecurus pratensis; BetNan, Betula nana; BetPub, Betula pubescens; DesCes, Deschampsia cespitosa; SalLan, Salix lanata; SalPhy, Salix phylicifolia; SorAuc, Sorbus aucuparia.

\begin{tabular}{lcccc}
\hline Species & $\begin{array}{c}\text { NDF } \\
(\mathbf{g ~ k g})\end{array}$ & $\begin{array}{c}\text { ADF } \\
\left(\mathbf{g ~ k g}^{-\mathbf{1}}\right)\end{array}$ & $\begin{array}{c}\text { Lignin } \\
\left.\mathbf{( g ~ k g}^{-\mathbf{1}}\right)\end{array}$ & $\begin{array}{c}\text { Res. ash } \\
\mathbf{( g ~ k g}^{-\mathbf{1}} \mathbf{)}\end{array}$ \\
\hline Betula nana & $328 \pm 23^{\mathrm{ab}}$ & $305 \pm 15^{\mathrm{abc}}$ & $154 \pm 7^{\mathrm{d}}$ & $19 \pm 1^{\mathrm{a}}$ \\
Betula pubescens & $315 \pm 16^{\mathrm{ab}}$ & $294 \pm 16^{\mathrm{abc}}$ & $123 \pm 10^{\mathrm{cd}}$ & $23 \pm 1^{\mathrm{a}}$ \\
Salix lanata & $376 \pm 25^{\mathrm{c}}$ & $345 \pm 22^{\mathrm{bd}}$ & $96 \pm 6^{\mathrm{bc}}$ & $41 \pm 4^{\mathrm{bc}}$ \\
Salix phylicifolia & $272 \pm 28^{\mathrm{a}}$ & $243 \pm 15^{\mathrm{a}}$ & $119 \pm 19^{\mathrm{cd}}$ & $22 \pm 2^{\mathrm{a}}$ \\
Sorbus aucuparia & $285 \pm 17^{\mathrm{ab}}$ & $269 \pm 12^{\mathrm{ab}}$ & $95 \pm 3^{\mathrm{bc}}$ & $28 \pm 3^{\mathrm{ab}}$ \\
Alopecurus pratensis & $631 \pm 22^{\mathrm{d}}$ & $388 \pm 13^{\mathrm{d}}$ & $65 \pm 7^{\mathrm{ab}}$ & $50 \pm 4^{\mathrm{c}}$ \\
Deschampsia cespitosa & $614 \pm 12^{\mathrm{d}}$ & $324 \pm 6^{\mathrm{bcd}}$ & $38 \pm 2^{\mathrm{a}}$ & $53 \pm 2^{\mathrm{c}}$ \\
Grassland & $500-550$ & $270-310$ & $30-50$ & \\
Cattle requirements & $330-450$ & $190-300$ & Max. 80 & \\
\hline
\end{tabular}

Calculated by one-way ANOva, differences among species for all chemical properties were significant $(P<0 \cdot 01)$. Using Tukey post hoc comparison test, species with the same letter were not significant. Chemical properties of fodder from Icelandic grassland (with dominant grasses Poa pratensis, Phleum pratense and Agrostis capillaris) follow Ragnarsson and Lindberg (2010), and the optimum range for cattle follows Kudrna (1998) and Whitehead (2000).

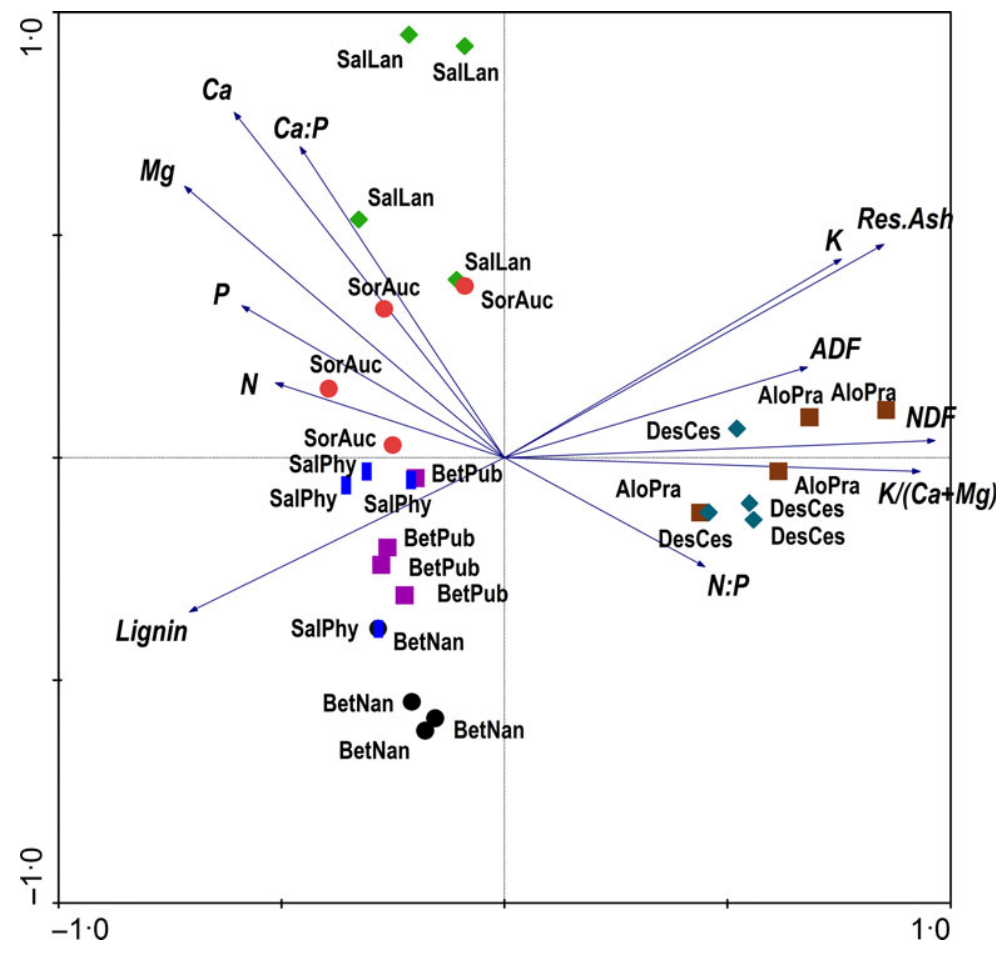

species were largely below the limit, whereas grasses were largely above the optimum NDF content required for cattle nutrition. Optimum contents of ADF for cattle nutrition were recorded in B. pubescens, S. phylicifolia and S. aucuparia. Other species were above the optimum range. Contents of lignin were substantially higher in woody species than in grasses.
In terms of animal nutrition requirements, leaves of woody species can be, and in the past may also have been, a valuable fodder for Icelandic livestock. The main problem for livestock metabolism is the relatively high lignin content in all woody species in comparison with grasses. Digestibility of the biomass generally decreases with an increase in lignin content 
(Cherney et al., 1993), and therefore, digestibility of the leaf fodder from all woody species is lower than that of the analysed grasses. From this point of view, the forage quality of leaves of woody species can be ranked in the order $B$. nana $<B$. pubescens $<$ S. phylicifolia $<S$. aucuparia $<S$. lanata. On the other hand, woody species can provide animals with considerable amounts of essential nutrients, particularly N, P, Ca and Mg. Nitrogen concentrations in the leaves of all the woody species were slightly higher than in the highly productive grass $A$. pratensis collected at the same time. Leaves of all the woody species had relatively high $\mathrm{P}$ concentration in comparison with that in A. pratensis. The lower concentration of $\mathrm{P}$ in the leaves of $B$. nana than in B. pubescens may possibly be associated with lower genome size, as $B$. nana is diploid $(2 n=28)$ and B. pubescens is a tetraploid $(2 n=56)$ species (Karlsdóttir et al., 2012). The existence of both higher $\mathrm{P}$ requirements and higher $\mathrm{P}$ concentration in grassland species with large genomes than in species with smaller genome size has been recorded previously (Šmarda et al., 2013). It is likely that the same mechanism is also valid for woody species. In addition, lower $\mathrm{N}, \mathrm{P}, \mathrm{K}, \mathrm{Ca}$ and $\mathrm{Mg}$ concentrations in leaves of $B$. nana than in B. pubescens are in agreement with the Ellenberg indicator value for nutrients (which is 2 for B. nana and 3 for B. pubescens; Ellenberg et al., 1991). Higher concentrations of $\mathrm{Ca}, \mathrm{K}$ and $\mathrm{Mg}$ in the leaves of $B$. pubescens can be explained by its preference for mineral soils with higher availability of basic elements than on the organic soils where $B$. nana frequently is a dominant species. Icelandic sheep frequently browse both these Betula species, especially B. pubescens (Thorhallsdottir and Thorsteinsson, 1993). This pattern is in agreement with the higher forage quality of B. pubescens compared with that of B. nana: higher concentrations of $\mathrm{N}, \mathrm{P}, \mathrm{Ca}$ and $\mathrm{Mg}$ and lower contents of NDF, ADF and lignin. This probably explains why, in the past, Icelandic farmers harvested B. pubescens for leaf fodder, whereas B. nana was rarely used (Gunnlaugsson, 1969).

\section{Possible use of leaf fodder in Iceland in the past}

Confirmatory written historical and archaeological records about the use of leaf fodder for livestock feeding in the North Atlantic Isles are scarce. In Iceland, we have no direct archaeological evidence about the use of the leaf fodder for the first two hundred years after landnám. There are, however, several written records about the use of $B$. pubescens woods for harvesting of leaf fodder as well as for the exploitation of woodlands for livestock (particularly sheep) winter grazing from the 16th to the 20th centuries
(Gunnlaugsson, 1969; Simpson et al., 2004; Sigurmundsson et al., 2014; Gudmundsson, 2015). The overwintering of livestock is described in the sagas, for instance in Egil's Saga from the 13th century, narrating the settlement of the chieftain Skallagrim in Borgarfjörður in SW Iceland (Hreinsson, 1997). The use of birch and willow twigs for foddering of livestock was also described in a diary by Jónsson (1877) as a desperate attempt to keep livestock alive in late winter and spring. Indirect archaeological indicators of woodland management include records of disarticulation scars, indicative of branch stripping and suggesting a form of coppicing (Church et al., 2007). Wood coppicing and/or pollarding are well-known practices of woodland management for the production of highquality leaf fodder (Rackham, 1989).

As documented by historical photographs from the 1920s, whole trunks of B. pubescens, together with twigs and leaves, were harvested and transported on horses to the farms in a similar way to mountain hay (see Figure Slb-c). Leaf-fodder collection, including young twigs with leaves, was probably an integral part of the collection of firewood and harvesting of construction timber, and this fodder could have been fed directly to livestock or dried for winter use (see Figure Sla). In addition, B. pubescens was harvested for charcoal production, which seems to have been very extensive in certain time periods in parts of Iceland (Fridriksson and Hermanns-Audardóttir, 1991; Church et al., 2007).

Although B. nana seems to have been rarely used for leaf-fodder harvesting in Iceland, this circumpolar species is an important summer forage species in other Arctic regions where reindeer are the principal herbivores (Marell et al., 2006; Kaarlejärvi et al., 2012). In the Faroe Islands, B. nana was a common species before the introduction of year-round livestock grazing (Hannon et al., 2005). Although it is little browsed by livestock in summer (Thorhallsdottir, 1981; Thorhallsdottir and Thorsteinsson, 1993), it is intensively browsed in winter by different herbivores at a highly sensitive period for the shrub (Chapin et al., 1980).

Leaves of both Salix species, especially S. lanata, are heavily browsed by sheep in Iceland, much more than B. nana or B. pubescens (Thorhallsdottir and Thorsteinsson, 1993). This observation is in good agreement with the measured nutritional value reported in this study (see Figure S2). Browsing of Salix species, with their high leaf-P contents, helps to maintain a good Ca:P balance, and Salix species are considered to the best woody forage species in Nordic regions (Forbes et al., 2010; Myking et al., 2013) and elsewhere as winter fodder (Hejcman et al., 2014). Salix spp. seems to have been much more common before the Norse settlement, both in Iceland (Hallsdóttir, 1995) and the 
Faroe Islands (Egelund et al., 2012). In Iceland, S. lanata was harvested for leaf fodder, although both Salix species have been used, particularly in years with poor grass growth (Gunnlaugsson, 1969).

Sorbus aucuparia is native to Iceland but was always a minor element in Icelandic woodlands (Hallsdóttir, 1995). Its leaves have relatively high forage quality, and this species is elsewhere selectively browsed by herbivores (Myking et al., 2013). Sorbus in Iceland was highly valued for construction purposes and was especially protected by law in the past (Grágás, the law of the Icelandic Commonwealth period). It is therefore unlikely that Sorbus aucuparia was ever harvested primarily for forage, although, because of its high nutritive value (see Figure 1), it is a highly selected species by grazing animals.

In Iceland, modern livestock farming is based on varieties of the highly productive forage grasses Phleum pratense, Poa pratensis, Festuca pratensis and particularly A. pratensis, which are sown as temporary leys on drained soils (Helgadóttir et al., 2013). The role of woody species as fodder for cattle and horses is very low today, but woody species are still a very important component of sheep diets on mountain pastures (Thorhallsdottir and Thorsteinsson, 1993). In Iceland, leaf fodder and other organs of woody species were probably always very important as livestock feed, especially in critical years such as (i) extremely cold years in which the production from grassland and bog forage was low, and (ii) years with volcanic eruptions, resulting in tephra accumulations that negatively affected the sward in the short term (although subsequently supplying a valuable and high-nutrient additions). In such critical years, woodland vegetation would stand above snow or tephra accumulations and could have served as the last emergent feed for survival of livestock. The extent of how critical the situation was for livestock feeding, and the survival of people is well illustrated by the effects on livestock numbers, which are known in Iceland since 1703 (summarized in Figure S3). There was an extreme decrease in livestock numbers after the Laki eruption in 1783, and this decline was followed by famine and a decline of the human population from approximately 50 000-40 000 (Vasey, 1991). As indicated by our research, forage quality of the leaf fodder of common woody species can, in some aspects, be higher than the forage quality of grasses and therefore be especially selected by herbivores. This property, related to Salix species, especially S. lanata, explains the browsing of this Salix species by sheep on mountain pastures (Thorhallsdottir and Thorsteinsson, 1993). Leaf fodder played an essential role in European and Norse farming for centuries (e.g. Austad, 1988), and it is, therefore, very likely that leaf fodder also played an important role in Iceland in the past, although there is little documentation of this. It would have contributed additional pressure on the limited forest resources in Iceland that were already under decline at the time of settlement (Erlendsson and Edwards, 2009), and deteriorating climate would have been further detrimental for the woodlands as the climate became colder during Little Ice Age (Ólafsdóttir and Guðmundsson, 2002; Lawson et al., 2007; Geirsdóttir et al., 2009).

\section{Acknowledgments}

We gratefully acknowledge the valuable advice of Aslaug Helgadottir, Pröstur Eysteinsson, Lilja Karlsdóttir, Friðpór Sófus Sigurmundsson and Hreinn Óskarsson. The study was funded by the Czech University of Life Sciences Prague, Projects CIGA 20134213 and IGA FTZ 20145018.

\section{References}

A O A C (1984) Official methods of analysis. Washington DC: Association of Official Agricultural Chemists.

A ustad I. (1988) Tree pollarding in Western Norway. In: Birks H.H., Birks H.J., Kaland P.E. and Moe D. (eds) The cultural landscape, past, present and future, pp. 13-29. Cambridge, UK: Cambridge University Press.

ter BraAk C. and Šmilauer P. (2002) CANOCO reference manual and CanoDraw for Windows user's guide: software for canonical community ordination (version 4.5). Section on Permutation Methods. Ithaca, NY: Microcomputer Power.

Brown J.L., Simpson I.A., Morrison S.J., Adderley W.P., Tisdall E. and Vésteinsson O. (2012) Shieling areas: historical grazing pressures and landscape responses in northern Iceland. Human Ecology, 40, 81-99.

BRyant J.P. and Kuropat P.J. (1980) Selection of winter forage by subarctic browsing vertebrates: the role of plant chemistry. Annual Review of Ecology and Systematics, 11, 261-285.

Bryant J.P., Tahvanainen J., Sulkinoja M., Julkunen-Titto R., Reichardt P. and Green T. (1989) Biogeographic evidence for the evolution of chemical defense by boreal birch and willow against mammalian browsing. American Naturalist, 134, 20-34.

Bryant J.P., Joly K., Chapin F.S., DeAngelis D.L. and Kielland K. (2014) Can antibrowsing defense regulate the spread of woody vegetation in arctic tundra? Ecography, 37, 204-211.

Chapin F.S., Johnson D.A. and McKendrick J.D. (1980) Seasonal movement of nutrients in plants of differing growth form in an Alaskan tundra ecosystem implications for herbivory. Journal of Ecology, 68, 189209.

Cherney D.J.R., Cherney J.H. and Lucey R.F. (1993) In vitro digestion kinetics and quality of perennial 
grasses as influenced by forage maturity. Journal of Dairy Science, 76, 790-797.

Church M.J., Dugmore A.J., Mairs K.A., Millard A.R., Cook G.T., Sveinbjarnard óttir G., Ascough P.A. and Roucoux K.H. (2007) Charcoal production during the Norse and early medieval periods in Eyjafjallahreppur, southern Iceland. Radiocarbon, 49, 659-672.

Church M.J., Arge S.V., Edwards K.J., Ascough P.L., Bond J.M., Cook G.T., Dockrill S.J., Dugmore A.J., McGovern T.H., Nesbitt C. and Simpson I.A. (2013) The Vikings were not the first colonizers of the Faroe Islands. Quaternary Science Review, 77, 228-232.

Dugmore A.J., Church M.J., Buckland P.C., Edwards K.J., Lawson I., McGovern T.H., Panagiotakopulu E., Simpson I.A., Skidmore P. and Sveinbjarnard ótTir G. (2005) The Norse landnám on the North Atlantic islands: an environmental impact assessment. Polar Record, 41, $21-$ 37.

Dugmore A.J., Church M.J., Mairs K.A., McGovern T.H., Newton A.J. and Sveinbjarnardóttir G. (2006) An over-optimistic pioneer fringe? Environmental perspectives on medieval settlement abandonment in Pórsmörk, South Iceland. In: Arneborg J. and Grønnow B. (eds) The dynamics of northern societies, pp. 335-345. Aarhus Denmark: Aarhus University Press.

Dugmore A.J., McGovern T.H., Vésteinsson O. Arneborg J., Streeter R. and Keller C. (2012) Cultural adaptation, compounding vulnerabilities and conjunctures in Norse Greenland. Proceedings of the National Academy of Sciences, 109, 3658-3663.

Edwards K.J., Schofield J.E. and Mauquoy D. (2008) High resolution paleoenvironmental and chronological investigations of Norse landnám at Tasiusaq, Eastern Settlement, Greenland. Quaternary Research, 69, 1-15.

Egelund B., Pertoldi C. and Barfod A.S. (2012) Isolation and reduced gene flow among Faroese populations of tea-leaved willow (Salix phylicifolia Salicaceae). New Journal of Botany, 2, 9-15.

Ellenberg H., Weber H.E., Düll R., Wirth V., Werner W. and Paulissen D. (1991) Zeigerwerte von Pflanzen in Mitteleuropa [Indicator values of plants in central Europe]. Scripta Geobotanica, 18, 1-248.

ERlendsson E. and Edwards K.J. (2009) The timing and causes of the final pre-settlement expansion of Betula pubescens in Iceland. The Holocene, 19, 10831091.

Forbes B.C., Fauria M.M. and Zetterberg P. (2010) Russian Arctic warming and 'greening' are closely tracked by tundra shrub willows. Global Change Biology, 16, 1542-1554.

FridriksSon Th.A. and Hermanns - Audardóttir M. (1991) Ironmaking in Iceland. In: Espelund A. (ed.) Bloomery ironmaking during 2000 years, pp. 5-11. Seminar i Budalen 1991. Trondheim, Norway: Budalseminaret

Geirsdóttir A., Miller G.H., Thordarson T. and Olafsdottir K.B. (2009) A 2000 year record of climate variations reconstructed from Haukadalsvatn, West Iceland. Journal of Paleolimnology, 41, 95-115.

GRÁGÁs - law of the Icelandic Commonwealth period (1992) Reykjavik: Mál og menning.

GUDMUNDSS ON B. (2015) Íslenskir sláttuhættir [Icelandic traditional mowing practices]. Reykjavik Hið íslenska bókmenntafelag, $352 \mathrm{pp}$.

Gunnlaugsson T. (1969) Um laufhey og laufheyskap [On leaf fodder and its making]. Ársrit Rxktunarfélags Norðurlands, 66, 76-84.

HALLSD ÓTTIR M. (1995) On the pre-settlement history of Icelandic vegetation. Icelandic Agricultural Science, 9, 1729.

Hannon G.E., Bradshaw R.H.W., Bradshaw E.G., Snowball I. and Wastegard S. (2005) Climate change and human settlement as drivers of lateHolocene vegetational change in the Faroe Islands. Holocene, 15, 639-647.

Hejcman M., Hejcmanová P., Stejskalová M. and PAVLŮ V. (2014) Nutritive value of winter collected annual twigs of main European woody species, mistletoe and ivy and its possible consequences for winter foddering of livestock in prehistory. Holocene, 24, 657-665.

Hejcmanová P., Stejskalová M. and Hejcman M. (2014) Forage quality of leaf-fodder from main broadleaved woody species and its possible consequences for the Holocene development of forest vegetation in Central Europe. Vegetation History and Archeobotany, 23, 607-613.

Helgadóttir A., Eythórsdóttir E. and Jóhannesson T. (2013) Agriculture in Iceland - a grassland based production. Grassland Science in Europe, 18, 30-43.

HJelle K.L. (1999) Modern pollen assemblages from mown and grazed vegetation types in western Norway. Review of Palaeobotany and Palynology, 107, 55-81.

HREINSSON V. (1997) The complete sagas of Icelanders, 1, pp. 50-51. Reykjavik: Leifur Eriksson Publishing.

Jóns s o N J. (1877) Jón Jónsson's Saga. The genuine autobiography of a modern Icelander. Fith-Roy Cole G.R. (ed.) Frazer's Magazine, ns 15, no 85.

KaArlejärvi E., Baxter R., Hofgaard A., Hytteborn H., Khitun O., Molau U., Sü̈gersten S., Wookey P. and OLOFSSON J. (2012) Effects of warming on shrub abundance and chemistry drive ecosystem-level changes in a forest-tundra ecotone. Ecosystems, $\mathbf{1 5}$ 1219-1233.

KarlsdótTir L., Hallsdóttir M., ThórsSon A.T. and Anamtha WA - J Óns Son K. (2012) Early Holocene hybridisation between Betula pubescens and B. nana in relation to birch vegetation in Southwest Iceland. Reviews in Paleobotany and Palynology, 181, 1-10.

Kohi E.M., de Boer W.F., Slot M., van Wieren S.E., Ferwerda J.E., Grant R.C., Heitkönig I.M.A., de Knegt H.J., Knox N., van Langevelde F., Peel M., Slotow R., van der WaAl C. and Prins H.H.T. (2009) Effects of simulated browsing on growth and leaf chemical properties in Colophospermum mopane saplings. African Journal of Ecology, 48, 190196. 
KRISTINSSON H. (2013) Flowering plants and ferns of Iceland. Reykjavík: Mál og menning.

KUdRna V. (1998) Produkce krmiv a výživa skotu [Feed production and cattle nutrition]. Prague: Agrospo.

Lawson I.T., Gathorne-Hardy F.J., Church M.J., Newton A.J., Edwards K.J., Dugmore A.J. and Einarsson A. (2007) Environmental impacts of the Norse settlement: palaeoenvironmental data from My'vatnssveit, northern Iceland. Boreas, 36, 1-19.

Ledger P.M., Edwards K.J. and Schofield J.E. (2014a) A multiple profile approach to the palynological reconstruction of Norse landscapes in Greenland's Eastern Settlement. Quaternary Research, 82, 22-37.

Ledger P.M., EdWARdS K.J. and SChofield J.E. (2014b) Vatnahverfi: a green and pleasant land? Palaeoecological reconstructions of environmental and land-use change. Journal of the North Atlantic, 6, 29-46.

Ledger P.M., Edwards K.J. and Schofield J.E. (2015) Taphonomy or signal sensitivity in palaeoecological investigations of Norse landnám in Vatnahverfi, southern Greenland? Boreas, 44, 197-215.

Mainland I. (2006) Pastures lost? A dental microwear study of ovicaprine diet and management in Norse Greenland. Journal of Archaeological Science, 33, 238-252.

Marell A., Hofgaard A. and Danell K. (2006) Nutrient dynamics of reindeer forage species along snowmelt gradients at different ecological scales. Basic and Applied Ecology, 7, 13-30.

Mc Govern T.H., Vesteinsson O., Fririksson A., Church M.J., Lawson I.T., Simpson I.A., Einarsson A., Dugmore A.J., Cook G.T., Perdikaris S., Edwards K.J., Thomson A.M., Adderley W.P., Newton A.J., Lucas G., Edvardsson R., Aldired O. and DUNBAR E. (2007) Landscapes of settlement in northern Iceland: historical ecology of human impact and climate fluctuation on the millennial scale. American Anthropologist, 109, 27-51.

Myking T., Solgerg E.J., Austrheim G., Speed J.D.M., Bohler F., Astrup R. and Eriksen R. (2013) Browsing of sallow (Salix caprea L.) and rowan (Sorbus aucuparia L.) in the context of life history strategies: a literature review. European Journal of Forest Research, 132, 399-409.

O gilvie A.E.J. and Jónsson T. (2000) 'Little Ice Age' research: a perspective from Iceland. Climatic Change, 48, $9-52$.

Ólafsd ÓtTiR R. and Guðmundsson H. (2002) Holocene land degradation and climatic change in northeast Iceland. Holocene, 12, 159-167.

RACKHAM O. (1989) The last forest: the story of Hatfield forest, p. 302. London: Dent.

Ragnarsson S. and Lindierg J.E. (2010) Nutritional value of mixed grass haylage in Icelandic horses. Livestock Science, 131, 83-87.

Reich P.B. and Oleksyn J. (2004) Global patterns of plant leaf $\mathrm{N}$ and $\mathrm{P}$ in relation to temperature and latitude. Proceedings of National Academy of Sciences of the United States of America, 101, 11001-11006.

Ross J.M. and Zutter C. (2007) Comparing Norse animal husbandry practices: paleoethnobotanical analyses from Iceland and Greenland. Arctic Anthropology, 44, 62-85.

Schofield J.E. and Edwards K.J. (2011) Grazing impacts and woodland management in Eriksfjord: Betula, coprophilous fungi and the Norse settlement of Greenland. Vegetation History and Archaeobotany, 20, 181197.

SiguRMUNDSSON F.S., GísLad ÓtTIR G. and ÓsKarsSON H. (2014) Decline of birch woodland in Pjórsárdalur from 1587 to 1938. Human Ecology, 42, 577-590.

Sigvald A Son J. (1967) Hvað er laufhey? Nokkur orð um steinefnamagn pess og grasafræðilega samsetningu. [What is leaf fodder? A few words on its mineral nutrient content and botanical composition.] ÁRsrit Ræktunarfélags Norðurlands, 67, 79-81.

Simpson I.A., Adderley W.P., Gudmundson G., HALLSD ÓtTir M., SigurgeirsSON M. and SNAESD ÓtTIR M. (2002) Soil limitations to agrarian land production in premodern Iceland. Human Ecology, 30, 423-443.

Simpson I.A., Vésteinsson O., Adderley W.P. and McGovern T.H. (2003) Fuel resource utilisation in landscapes of settlement. Journal of Archaeological Science, 30, 1401-1420.

Simpson I.A., Guðmundson G., Thomson A.M. and Cluett J. (2004) Assessing the role of winter grazing in historic land degradation, Mývatnssveit, northeast Iceland. Geoarchaeology, 19, 471-502.

Šmarda P., Hejcman M., Březinová A., Horová L., Steigerová H., Bureš P., Hejcmanová P. and SCHellberg J. (2013) Effect of phosphorus availability on the selection of species with different ploidy levels and genome size in a long-term grassland fertilization experiment. New Phytologist, 200, 911-921.

Sut the N.F. (2010) Mineral nutrition of livestock 4th edn. Wallingford UK: CABI.

Tedeschi L.O., Ramírez-Restrepo C.A. and Muir J.P. (2014) Developing a conceptual model of possible benefits of condensed tannins for ruminant production. Animal, 8, 1095-1105.

Thomson A.M. and Simpson I.A. (2007) Modeling historic rangeland management and grazing pressures in landscapes of settlement. Human Ecology, 35, 151168.

Thorhallsdottir A.G. (1981) Beitevalg hos sau og rein pa Vesturöræfi Ísland. [Plant selection and grazing behaviour of sheep and reindeer in Vesturoraefi, east Iceland.] MSc. Thesis, Agricultural University of Norway, As, Norway. 112 p.

Thorhallsdottir A.G. and Thorsteinsson I. (1993) Behaviour and plant selection. Búvísindi, 7, 59-77.

Thorvaldsson G. (1998) Áhrif veðurpátta á byrjun gróanda og grænku túna og úthaga. [Climatic factors influencing leaf initiation and spring plant growth in cultural and natural pastures.] Ráđunautafundur, 155-163.

Trbojević N., Mooney D.E. and Bell A.J. (2011) A firewood experiment at Eriksstađir: a step towards quantifying the use of firewood for daily household needs in Viking age Iceland. Archaeologica Islandica, 9, 29-40. 
VASEy D.E. (1991) Population, agriculture, and famine Iceland 1784-1785. Human Ecology, 19, 323-350.

Vésteinsson O. and Simpson I.A. (2004) Current issues in Nordic archaeology. In: Proceedings of the 21st Conference of Nordic Archaeologists, 6-9 Sept 2001, pp. 181-187. Akuyeri, Iceland: Society of Icelandic Archaeologists.

Villalba J.J., Miller J., Ungar E.D., Landau S.Y. and Glendinning J. (2014) Ruminant self-medication against gastrointestinal nematodes: evidence, mechanism, and origins. Parasite, 21, 31.

Whitehead D.C. (2000) Nutrient elements in grassland: soilplant-animal relationships. Wallingford, UK: CABI.

\section{Supporting Information}

Additional Supporting Information may be found in the online version of this article:

Figure S1. In the past, horses were used for the transport of ( $a$ and b) wood and (c) meadow hay from mountains to settlements. Trunks of Betula pubescens were transported with twigs and leaves together.

Figure S2. Photographs showing (a) Betula nana, a dominant dwarf shrub on large areas in uplands. (b) Remnants of natural forests with dominant Betula pubescens trees and with Betula nana in understorey. (c) In uplands, sheep browsing (on the left side) can prevent regeneration of woody species, Salix lanata (shrubs with grey leaves) and S. phylicifolia (shrubs with green leaves), particularly. (d) Shrubs of S. phylicifolia are well browsed by sheep. (e) Alopecurus pratensis was introduced as a high quality forage species used for hay and recently also for haylage production. (f) Deschampsia cespitosa is a tussock-forming weedy grass of low palatability infesting productive grasslands.

Figure S3. Graphs showing changes in number of (a) cattle, (b) horses, (c) sheep and (d) goats in Iceland between years 1703 and 2012 . 